\title{
Stakeholder Participation in Growing Spirit of Saving for Children in Beji Timur, Depok
}

\author{
Kartika Nuringsih ${ }^{1 *}$ \\ ${ }^{1}$ Faculty of Economics and Business, Tarumanagara University, Jakarta, Indonesia \\ kartikan@fe.untar.ac.id \\ Khairina Natsir ${ }^{2}$ \\ ${ }^{2}$ Faculty of Economics and Business, Tarumanagara University, Jakarta, Indonesia \\ khairinan@fe.untar.ac.id
}

(Received June 04, 2021, accepted August 01, 2021)

\begin{abstract}
In line with the Indonesian money-saving campaign, community service activities were carried out to foster interest in money-saving among kindergarten students in Beji Timur, Depok. These activities had been carried out since the end of March and ended in June 2021 as the culmination of the theme "Ayo Menabung"(let's save money), with the target audience of Raudhatul Athfal Toufiqurrahman students. The community service partner was BRI Agroniaga Depok Branch which provided facilities for opening student saving accounts and sponsoring other educational activities. A total of 32 saving accounts had been realized, and in June 2021, the peak of the "Ayo Menabung" event was held in the form of the practice of money deposit in a bank. Each student has an account opened with an initial deposit of IDR.20,000, then in the practice of saving, each student was given IDR.200,000 to be deposited in their accounts. During the evaluation period, another IDR.30,000 was added, so that each student had a total saving of IDR.250,000. As a continuation, the children would maintain their savings account independently, facilitated through a pick-up service from the bank, supported by motivation from parents and teachers to keep the children's consistency in saving money. Because it was still in a pandemic situation, bank tellers or customer service staffs would come to school to serve the children practicing money deposit. Through this community service, the children got new knowledge about banking and the benefits of savings. In addition, it also provided financial knowledge to the parents and teachers. There was almost no significant problem in the implementation of the service activities, except for the constraints more related to the Covid-19 pandemic so that there was a necessary extra effort for activities to coordinate related parties. The commitment and participation of stakeholders in information dissemination and actualization of student money-saving practices can foster a culture of money-savings while the collaboration creates a mechanism to ensure sustainable moneysaving habit among children.
\end{abstract}

Keywords: interest in saving; stakeholder participation; kindergarten 


\section{Introduction}

Today, the development of information technology and the retail sector is very fast. This has an impact on the growth of shopping places that are increasingly prevalent and near to housing or school areas. In addition, promotions and advertisements for various products are getting more intense on social media. This condition raises the interest in buying goods so that it is at risk of shaping wasteful behavior among children. Likewise, adults unconsciously give negative examples in the form of irresponsible shopping so that indirectly it shows consumption behavior that leads to consumerism. This has impact that changes the behavior of a person to buy goods excessively without seeing the useful value of the item or just simply do window shopping. Meanwhile, from the perspective of the global community, consumptive behavior is relevant to the target of the Sustainable Development Development Goals (SDGs). The $12^{\text {th }}$ target mentions "Responsible Consumption and Production", which is assumed to be the majority of the world's population consuming goods that are not their primary needs so that this habit causes a waste of resources. Therefore, SDGs encourage the adoption of consumption and production patterns responsibly to save material, including through reuse and recycling. This statement is relevant to the prevention of consumerism, so an approach is needed to reduce the impact of this consumptive behavior. This habit should be anticipated to create community responsibility in managing their spending money.

One approach to suppress consumerism is through money-saving habit so that one can regulate the use of one's money by saving and using it for future purposes. According to regulations, the government already has policies related to financial inclusion, including the Indonesian Money-saving Movement with a target group of children or school students. Likewise, the Financial Services Authority is campaigning for the "Ayo Menabung" movement to enhance the culture of money-saving society through financial service products and supporting the financing of national development. According to the Deposit Insurance Institution, the total public savings in January-August 2017 grew 5\% compared to 2016, as well as per May 2018 total savings increased by $6.07 \%$ compared to May 2017 . This number also grew by $7.57 \%$ as of August 2019 compared to 2018. It also recorded that the number of public deposits as of November 2020 increased by $10.91 \%$ compared to the same period in 2019. Meanwhile, in January 2021 while there was an increase of $10 \%$, but compared to December 2020, the nominal amount of public deposits decreased by $1.45 \%$. It shows a series of growth in the amount of savings amid Indonesian people. To strengthen this, events that encourage children's 
awareness to do money-savings activities need to be facilitated. Some people think that saving is practiced after having a lot of money so that before having enough money they usually do not have the need to do saving. Behavior of savings is a person's action in shaping his present or future by trying to apply a modest lifestyle or suppress the consumerism side. Generally, the habit of money-saving gives a positive impact on the welfare of society and tends to increase the standard of living among people. For these reasons, education to support the culture of money-saving needs to be introduced since an early age, like one of which was carried out with the partnership with Raudhatul Athfal Toufiqurahman in Beji Timur, Depok.

As an educational social institution under the Toufiqurrahman Foundation, the school of Raudhatul Athfal is a formal early childhood education level or equivalent to kindergarten which is supervised by the Ministry of Religion. The school is concerned about introducing money-saving activities to the students. Even though it was limited to a plastic piggy bank, this habit of money-saving is accustomed to children. Under the guidance of Mrs. Indah, S.Pd. as the principal of the school, and Mrs. Eli as the accompanying teacher, the school tried to introduce the habit of money-saving to children. The pioneering money-saving movement has been carried out through community services since before the pandemic period (Nuringsih et al., 2020). In the activity, children were motivated to save even though the savings are limited to pocket money from their parents and from charity activities during the month of Ramadan. The way to disseminate the motivation was still using posters of the Indonesian Money-saving Movement and using the "piggy bank" made of plastic or cans to store money. Nevertheless, the children felt happy and interest has been formed in saving so this encouraged them to a more serious level of engagement. To develop their experiences in carrying out money-saving activities, support was made through banking institutions. Therefore, the team from Tarumanagara University collaborated with the school to foster the spirit of saving among children.

Actually, along with the cultural movement of money-saving, education was developed through "Ayo Menabung" movement supported by the banking institutions. This is in line with the savings program organized by PT Bank Rakyat Indonesia Agroniaga Tbk, Depok branch office. The program targets students in Depok City from kindergarten to high school level, to save money through banking institutions. The saving model is very simple so that students are not burdened by administrative costs or the minimum amount of balances in their saving 
account. Thus a collaborative program was carried out by the Tarumanagara University Community Service Team, in cooperation with BRI Agroniaga Depok Branch, and Raudhatul Athfal Toufiqurrahman in Beji Timur to pioneer the "Ayo menabung di Bank" (let's deposit money in the bank) movement. The goal of this program was to foster children's interest in money-saving so that this interest will develop into saving behavior from an early age.

Thus, Raudhatul Athfal Toufiqurrahman was chosen as the target audience to be involved in the money-saving program in Beji Timur, Depok. This program was expected to overcome the limitations of teachers in fostering a culture of saving of their students from an early age. Therefore, the collaboration of Tarumanagara University and BRI Agroniaga was to support and improve the creativity of teachers and parents of the students in encouraging them to do money-saving. The next expectation was that this participation can reduce the potential for consumerism from an early age. Adjusting to the conditions of the target audience, the problem formulation was focused on how to foster sustainable money-saving behavior in early childhood, especially in Raudhatul Athfal Toufiqurrahman School. Through this collaboration, it was expected that it can foster children's interest and parental participation in encouraging their children to do money-saving through banking institutions. In addition, it would develop children's knowledge about the benefits and roles of banking institutions.

\section{Method}

The method of the activity through information dissemination about the benefits of saving and the practice of saving in a bank begins with the opening of an account book. The dissemination approach is one of the most common approaches used in community service program (Marlina \& Iskandar, 2019). Moreover, as a solution to partners problems, assistance was given to the students in the kindergarten level in bank account opening while also develop the children's experiences about money-saving. Apart from that, motivation would be given to parents to always remind their children about the importance of money-saving. Khairina Natsir gave the dissemination material related to the programs while Kartika Nuringsih played the role of coordinator between BRI and the school. Those targets are the goals of community service activities in this kindergarten. 
The activities were carried out in Raudhatul Athfal Toufiqurrahman school, located on Jln. Baitul Rohim at Beji Timur, Depok. It took place from March to June 2021 by involving parents, teachers, and the students. Further participation of the partnersip was as follows: (1) partners welcoming the initial visit of the Tarumanagara University Community Service Team to observe the launching of the community program about money-saving for children, (2) to be active in discussions to identify priority problems, solutions, and target outcomes, (3) the school principal was sharing about limitations while encouraging money-saving habit (4) the association of teachers and student-parents or called "POMG" supports the approach or way of maintaining the sustainability of the program, and (5) partners be ready to take part in evaluation and monitoring related to the service activity. The first evaluation was in the form of a questionnaire that was given to the parents via WhatsApp, while the second evaluation relates to the motivation of money-saving among children. It would reflects the degree of the parents as well as the children's seriousness in saving activities. Hence, the evaluation result can be used for planning further activities.

Furthermore, the agendas of the event were as follows: (1) discussing with the school principal about money-saving activities and how to open a saving account, (2) coordinating with the BRI Agroniaga Depok Branch Office represented by Mr. Roky Susanto Putra as the funding officer, (3) discussing with the parents about the implementation process of "Ayo Menabung", preparing requirements, and encouraging parents motivation regarding the continuation of the money-saving program, (4) filling out a saving account application form and open a saving account/book, (5) preparing materials to motivate the parents and children in money-saving movement, (6) carrying out the practice of money-saving with limited representation by the community service team, and (7) monitoring and evaluating the continuation of money-saving activities through coordination with the BRI bank. These stages were carried out while adhering to health protocols during pandemic, in Raudhatul Athfal Toufiqurrahman School. During pandemic, the customer service officer comes to school to accompany children to take turns making money deposit on their own just like in the bank although just in a form of practice done at the school.

To encourage the partner in money-saving behavior, the activities were made aligned with the financial literation. Hence, the transferring model to the partner consists of two purposes. Firstly, assistance in opening a savings account. Approaches to partners were carried out through mentoring and the dissemination of money-saving behavior. The method has relevance 
to the saving campaign to improve the culture of money-saving among the community so that it also supports the financing of national development. A person's interest in saving is related to the person's background of knowledge or financial literacy. In line with a prior study, Natsir et al., (2020) identifies a significant relationship between financial literacy and financial behavior so that this knowledge supports decisions in family financial management, including saving. Likewise, Nuringsih et al. (2020), notes a similar interest in financial literacy, especially related to the introduction of money-saving concept to children in order to shape modest behavior from an early age. For this reason, the activity raised the theme of simple financial literation.

Conceptually, in the behavioral study, several factors form the saving behavior. Following the theory of planned behavior (TPB), it is stated that subjective norm is one of the factors influencing saving behavior in which parties related to subjective norms come from their immediate environments such as parents, family, or teachers. Thus the role is potentially empowered to encourage saving behavior (Jamal et al., 2015); (Widyastuti et al., 2016); (Garcia et al., 2011); (Sirine \& Utami, 2016). Based on these studies, it is concluded that the family environment has a strong influence on saving behavior so that to foster children's behavior it is necessary to involve those who have closest relationship to the children.

For these considerations, the education was carried out with students as an effort to foster a positive attitude towards saving at an early age. This Community Service activity is to encourage saving behavior. Thereby, the children of Raudhatul Athfal Toufiqurrahman had the opportunity to get savings accounts simultaneously at BRI Agroniaga Bank Depok Branch. Dissemination events were carried out through videos by uploading to YouTube channel by reason of the pandemics. The dissemination conveyed messages such as about the benefits of saving, how to deposit money in the bank, and how to manage money.

Secondly, financial literacy dissemination. In line with the development of financial inclusion in Indonesia, the money-saving behavior is one of the habits that is being promoted by the government. The Financial Services Authority or called as OJK has been campaigning for the money-saving movement since 2016 to enhance the people's money-saving habit in financial service products and support national development. As a continuation, the OJK in 2019 planned to declare a "National Savings Day" so that through this movement the public would have an insight into financial literacy. The dissemination was given to the parents and teachers 
association with the goal to provide knowledge or financial literacy to parents and teachers. The scope included examining government activities in the saving movement, important aspects of financial literacy, and others. The campaign was launched by the Financial Services Authority together with the Financial Services Industry in conjunction with World Savings Day on 31 October. The Saving Movement as an application of the Presidential Regulation of the Republic of Indonesia Number 82 of 2016 concerning the National Strategy for Financial Inclusion. The goal is to revive a culture of saving and investment for the Indonesian people. The public is introduced to a variety of financial products/services as a means of saving or investing in formal financial service institutions to increase the liquidity of domestic savings to contribute to financing national development and the community's economic independence.

According to the Financial Services Authority, financial literacy is knowledge, skills, and beliefs that influence attitudes and behavior to improve the quality of decision-making and financial management to achieve prosperity. Various aspects in it include (1) introduction to the concept of shopping as a fulfillment of basic needs, (2) introduction to the concept of saving in traditional and modern terminology, (3) introduction to the concept of sharing based on local wisdom, religious teachings, and the state, and (4) introduction to the concept of bad practice and financial crime (Kemendikbud, 2017). Specifically, for supporting the literation among members of the school in practice it can be optimized through the internal facility of schools such as canteens, cooperatives, libraries, or reading corners as a means of a simple financial literacy. These facilities are used to direct children in understanding money and how to use it wisely. Through this approach, children or school students indirectly learn to understand about using their finances sparingly or carefully.

\section{Results and Discussions}

Raudhatul Athfal Toufiqurrahman School as a partner for Community Service program is a kindergarten-level formal school managed by the Toufiqurahman Foundation at Beji Timur, Depok. The kindergarten is led by Mrs. Indah as the principal. The foundation manages the levels of kindergarten education, Madrasah Ibtidaiyah, Madrasah Tsanawiyah, and Pharmacy Vocational High School, but those selected as the initial pilot of the program were only kindergarten students to foster a spirit of saving from an early age. 
Furthermore, the partner that facilitated saving activities is PT Bank Rakyat Indonesia Agroniaga Tbk. (BRI Agro) Depok Branch Office which is located at Jl. Margonda Raya No. 198A RT 03/RW 08 at Kemiri Muka, Beji Subdistrict, Depok. BRI facilitates the account opening process, willing to provide information about account balances for savings evaluation activities. In addition, the institution is willing to sponsor banking education activities, for example, student visits to the banks in situations outside the pandemic period. This opportunity will increase students' knowledge and experience in getting to know about banking and the benefits of saving for the future.

Previously, students were initial targets to be fostered for interest in money-saving even though it is simply in practice of saving in a piggy bank. This previous event was held before the Covid-19 Pandemic so that there was no health protocol done during the event. The activities started within coverage of the school, then began to involve an agreement with BRI Agro. Following the agreement, the activities were attended by 32 students consisting of 9 early childhood kindergarten students and the rest were older kindergarten students. The program began with a meeting on March 29, 2021, with the agenda of coordinating with the principal and three accompanying teachers, namely Mrs. Ayu, Mrs. Eli, and Mrs. Ina. In this activity, it was successfully decided to realize "Ayo Menabung" with BRI Agroniaga Depok Branch. Further agenda, on April 5, there was coordination with BRI Agroniaga, represented by Mr. Roky Susanto Putra as the funding officer. As a result, an agreement was obtained that BRI helped to provide savings account for children with certain criteria without administration fees and only an initial account opening deposit of IDR 20,000. There was no administration fee because this savings account was not accompanied by an ATM card so that it confined children to always active in saving, while not given the ease to withdraw these savings. After that, on April 9, 2021, the Community Service Team from Tarumanagara University, POMG, and BRI coordinated to fill out an account opening application with the target of creating 32 student savings accounts. However, due to the early holiday of the month of Ramadhan, saving practice activities were scheduled for June 2021 as the highlight of the theme of "Ayo Menabung". In this activity customer service officers from the bank came to school so that children can practice money deposit at the school. The activities were as follows: 


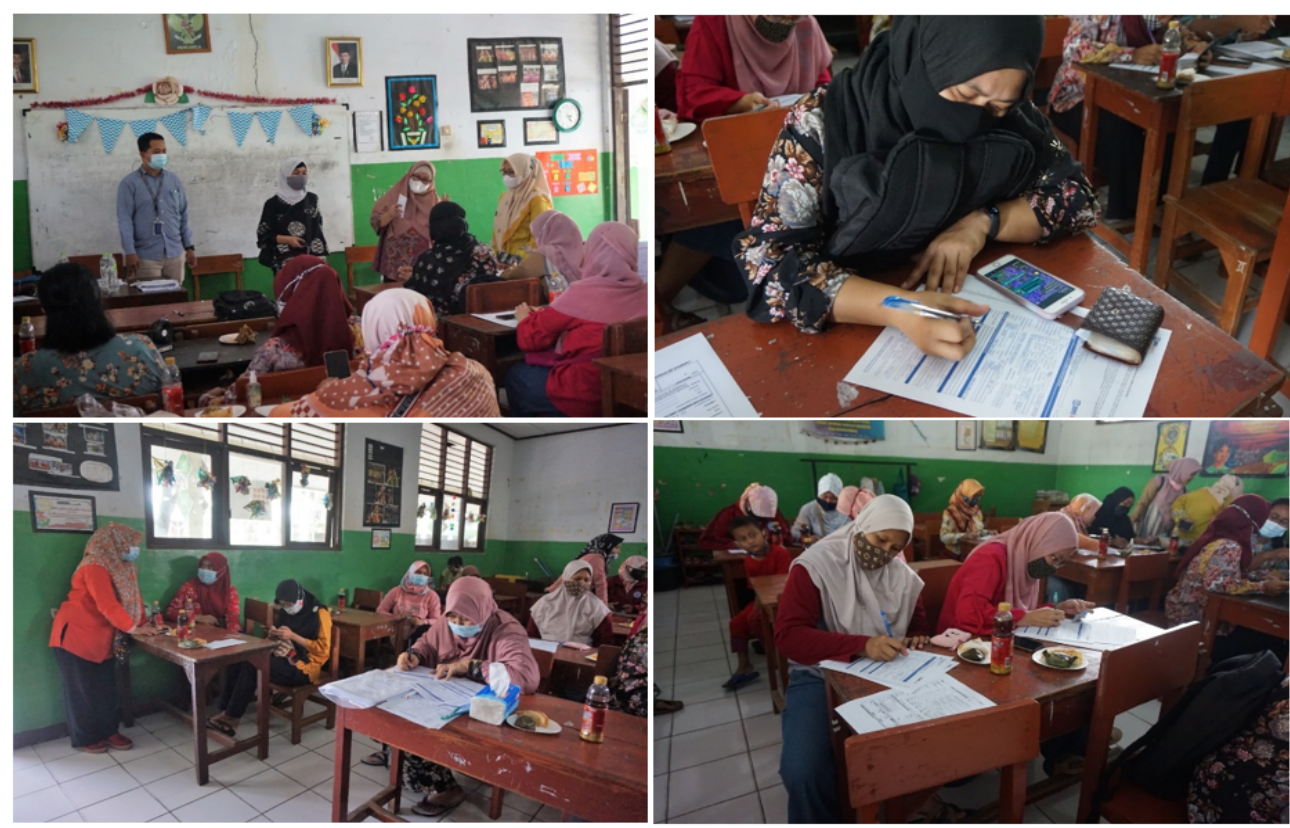

Fig. 1. Filling in the form for opening a savings account

Figure 1 shows the process of filling in the savings account form where Mr. Roky was explaining the benefits and criteria for this type of student saving account. Children have the opportunity to get a banking account, collectively made by the Depok Branch of the BRI Agroniaga Bank with requirements in the form of photocopies of their parents' ID cards, family register cards, and birth certificates. The initial amount of funds required to open an account was IDR 20,000, then during the practice activity of money-saving, the children were provided with IDR 200,000 each, so the total savings accounted IDR 220,000. During the evaluation activity, another IDR 30,000 added for each student so that the balance of each savings account topped to IDR 250,000 at the end of the program. For continuing habit, additional saving deposit were made independently by each student so that teacher motivation and parental commitment were very important to ensure the sustainability of the money-saving habit.

Furthermore, on April 21, 2021, the opening of all saving accounts has been completed, and the saving account book could be used for children's saving activities. Henceforth, the saving account book was stored at school, and once a week BRI officers would take savings deposits through the school. The money was deposited independently by each student. The minimum value of the next saving deposit was IDR 10,000 per account and the pick-up service provided by the bank was very helpful and made it easier for parents and teachers to keep on motivating their children to deposit savings. Savings dissemination events are delivered through videos while in pandemic conditions. On this occasion, the initial dissemination of "Ayo Menabung" 
was carried out to the parents of students in the hope that it could motivate their children about the benefits of saving. However, dissemination to children would be given in June 2021 along with the tutorial session of saving practices. The dissemination would contain messages and stories about the benefits of saving, how to deposit savings in a bank, how to manage money, and other financial literacy. This result was a realization of original activities (Nuringsih et al., 2020) with the support of financial institutions or banks.

Finally, based on the results of the evaluation, it was stated that the parents were enthusiastic about participating in the opening of the account where $72 \%$ had submitted the forms to the bank officer and had established their children saving account, while the rest were catching up. Thus the saving account book for 23 students was ready to be realized while the rest was just waiting so that by May 2021 it was targeted that all students would get a saving account. From the parents' side, they were also willing to motivate and continue independently adding their children's deposits at a later date. Apart from that, the teacher was willing to coordinate saving deposits which would later be made through a pick-up service from the bank so that this collaboration is expected to support the sustainability of the saving program for children in Raudhatul Athfal Toufiqurrahman.

This activity manages to combine collaboration between stakeholders among Tarumanagara University, BRI Agro, and Raudhatul Athfal Toufiqurrahman in pioneering the "Ayo Menabung" activity at Beji Timur. This is relevant to the theory of planned behavior that stated subjective norms as one of the factors influencing the behavior. Therefore, stakeholders can be empowered as a model for realizing money-saving activities. In addition, the immediate environment such as parents, family, or teachers is very effective in encouraging and maintaining the spirit of money-saving sustainably. Thus this mechanism can form a positive attitude and self-confidence to make money-saving as a habit, so that in the long term it can suppress shopping impulse or suppress consumerism among the children. It is a part of the role of social norms in encouraging the intention in money-saving. This collaboration involves some stakeholders in making dissemination for parents and children about the benefit of saving. It shows the participation such as university, banking, and teachers as social support in driving parents to be aware with saving behavior. Hence, it would form the money-saving habit among children. It is an empowerment of family environment in driving the money-saving behavior such as mentioned (Widyastuti, Suhut \& Sumiati., 2016; Sirine \& Utami, 2016; Jamal et al., 
2015; Gracia et al., 2011), especially in children. Based on these considerations, the community service activities was successful in fostering the spirit of money-saving among children and their mothers.

This momentum relates to the effort to encourage the culture of money-saving in the society. It is known that the ratio between total savings and national income (savings to GDP ratio) in Indonesia is around $31 \%$ or it is lower than Singapore (49\%), the Philippines (46\%), or China (49\%). The low culture of money-saving can be seen in the decrease of the value of Marginal Propensity to Save (MPS) or the desire to do savings, even though the value of GDP per capita increases. This is influenced by the level of public access to formal financial institutions where according to 2014 World Bank data it was $36.1 \%$. This percentage is relatively lower compared to several countries such as Thailand, Malaysia, and Singapore (Nordiansyah, 2016). Due to the considerations of the above matters, the community needs to be encouraged to do moneysaving. Financial literacy should be given starting from the school environment, family, and community. The expected goal of this program is the shaping of a good perception of moneysaving habit from the parents so that they can motivate their children to do money-saving and eventually form a positive attitude for children to save money for the future.

The educational target for the money-saving movement is a group of school students with consideration that not all students have a savings account. This is different from the college student group which is systemized to have a savings account. However, this activity is not just increasing the number of savings accounts among students but has an important goal of building positive habits in financial management. Through the habit of saving, it can form modest behavior so that one of the impacts is preventing consumerism from an early age. Although simple, this activity supports the Indonesian Money-savings Movement as promoted by the government. Globally, it is also related towards SDGs specifically in ensuring "responsible consumption and production" in which responsible consumption can anticipate consumerism through saving. Thus, through collaboration in pioneering the let's save money, it is expected that it can reach other target audiences so that more people and students are literated about finances and form of sustainable money-saving habit. 


\section{Conclusion}

In line with the Indonesian Savings Movement, the goal of the activity fosters the interest in saving among kindergarten students. This agenda has been planned since the end of March and ends in June 2021 as the culmination of the theme. The activity was carried out with BRI Agroniaga Depok Branch to open accounts for Raudhatul Athfal Toufiqurrahman students. A total of 32 savings books have been realized so that in May 2021 the peak of this event is held to the practice of saving at a bank. Because in a pandemic situation, the customer service comes to school to carry out the practice of saving. Thus, the commitment of parents and teachers is very important in motivating children to save so that they can maintain their savings. Through this activity, the children gained new knowledge about banks. This information is an insight into the role of banking and the benefits of saving for children. Besides providing financial literacy to teachers and parents, stakeholder collaboration between Tarumanagara University and BRI is a form of support for teachers so that it can increase the creativity of teachers and parents in encouraging children's interest in saving.

As a recommendation, either after or while still in a pandemic situation, this program can be expanded to other target audiences in Beji Timur such as Islamic boarding schools or orphanages so that more parties are financially literate and have savings for the future. If possible the same activities with BRI can be carried out in these groups, although they still maintain activities in Toufiqurrahman. But what is certain is that the collaboration will continue in continuing saving activities through a pick-up service for further savings deposits through schools. There are almost no significant obstacles in the implementation of this activity, except related to the pandemic period so that separate stages are needed in coordinating with partners, parents, and teachers. In the end, the commitment of stakeholders in the dissemination and realization of "Ayo Menabung”, can encourage a spirit of saving in children so that the optimization of this togetherness can be directed as a mechanism to ensure sustainable saving behavior.

\section{Acknowledgments}

We would like to thank the Tarumanagara University Research and Service Institute (LPPM) for funding this community service activity and say thanks to Mrs. Indah SW, S.Pd as the Head of Raudhatul Athfal Toufiqurrahman School as well as accompanying teachers and all parents 
of students for togetherness in activities of "Ayo Menabung". We also would like to thank the BRI Agroniaga Depok Branch Office represented by Mr. Roky Susanto Putra for the support of opening student saving accounts in this event.

\section{References}

Garcia, M. T. M., Barros, C., \& Silvestre, A. (2011). Saving behaviour: Evidence from Portugal. International Review of Applied Economics, 25(2), 225-238. https://doi.org/10.1080/02692171.2010.483467

Jamal, A. A. A., Ramlan, W. K., Karim, M. A., Roslemohidin, \& Osman, Z. (2015). The Effects of Social Influence and Financial Literacy on Savings Behavior: A Study on Students of Higher Learning Institutions in Kota Kinabalu, Sabah. International Journal of Business and Social Science, 6(111), 110-119.

Kemendikbud, T. G. (2017). Materi Pendukung Literasi Finansial. Gerakan Literasi Nasional, 1-41. http://gln.kemdikbud.go.id/glnsite/buku-literasi-finansial/

Marlina, N., \& Iskandar, D. (2019). Gerakan Menabung Sejak Dini di Rowosari. Pengabdian Vokasi, 01(01), 27-32.

Natsir, K., Setini, M., \& Arifin, A. Z. (2020). The Influence of Income and Financial Literacy on Financial Satisfaction through Financial Behavior as a Mediating Variable. In Urban Development and Life style (pp. 105-115). Nova Science Publishers Inc, New York.

Nuringsih, K., Edalmen, Nuryasman, M., \& Priana, V. (2020). “ Ayo Menabung dan Ayo Berbagi ": bersama RA Toufiqurrahman di Beji Timur Depok. SENADA -Semangat Nasional Dalam Mengabdi, 1(2), 152-161.

Sirine, H., \& Utami, D. S. (2016). Faktor-Faktor Yang Memengaruhi Perilaku Menabung Di Kalangan Mahasiswa. Jurnal Ekonomi Dan Bisnis, 19(1), 27-52.

Widyastuti, U., Suhud, U., \& Sumiati, A. (2016). The Impact of Financial Literacy on Student Teachers' Saving Intention and Saving Behaviour. Mediterranean Journal of Social Sciences, 7(6), 41-48. https://doi.org/10.5901/mjss.2016.v7n6p41 